\title{
Citizen Involvement in the Decision-Making Processes of Environmental and Spatial Planning, and it's Influence on Public Participation: a Case Study of Lisbon
}

\author{
Vanda Carreira $^{1 *}$, João Reis Machado ${ }^{1,2}$, Lia Vasconcelos ${ }^{1}$ \\ ${ }^{1}$ Faculty of Sciences and Technology, New University of Lisbon (FCT-UNL), Quinta da Torre, \\ Campus Universitário, 2829-516 Caparica, Portugal \\ ${ }^{2}$ Geographical Institute of Lisbon, Rua da Artilharia, 1099-052 Lisboa, Portugal
}

\begin{abstract}
The study was developed in a sample of 250 individuals $(n=250)$ over 18 years of age who were eligible voters in Portugal, and aimed primarily to evaluate citizens' opinions of the public participation context of environmental and spatial planning, considering two points, (1) who should be involved in the decisionmaking process, and (2) during which stage of the decision-making process of public policies citizens should be involved and should participate. The majority of the sample $(64.8 \%)$ reported that do not participate in environmental and spatial planning policies. Some $94.8 \%$ of the sample considered that all the stakeholders (governments, private organizations, and common citizens) should be involved in public policies, and the majority of respondents (82.4\%) considered that the population should participate and be involved "from the very beginning of the project development"-that is, at the embryonic idea time. The type of value that every citizen attaches to politicians' actions and/or decisions and the level of public participation in environmental and territory planning policies, resented a statistically significant relationship $(p=0.014)$. Citizens can and should, be involved in decision-making processes in the early stages and should have the opportunity to truly influence the decisions handed down. It is the planner's obligation to valorize information and build partnerships, to document participation activities and their results, and to explain at the end how the participation influenced the final decisions made.
\end{abstract}

Keywords: Citizens; Public participation; Decision-Making Processes; Environment; Spatial planning

\section{INTRODUCTION}

The planning process involves rational decision-making, which identifies objectives, designs implementation proposals, and combines operating means to implement actions and review results in relation to initial objectives [1]. In a more contemporary perspective, it is a negotiation process that aims to coordinate decisions, manage conflicts, and build consensus among the various actors involved and interested in planning territory transformation. Thus, it is a continuous, cyclical, and deliberate prescriptive and prepositional activity that materializes in different models, linked to decisions and actions that involve value judgments, or reference patterns that allow assessment of their (i.e., the models') effectiveness [2,3]. There are two prevailing decision-making models in Portugal: the bureaucratic or rational model, and the collaborative or interactive model. The bureaucratic or rational model was authored by Weber [4] and is based on the adequacy of the existing means to achieve the intended aims, ensuring maximum efficiency [5]. Here the public and private spheres do not intermingle, thus denying that conflict of interest, human limits, the key role of knowledge, affective relationships, and the values of individuals are involved in the decision [6, 7]. As for the collaborative or interactive model $[8,9]$, it is characterized by overcoming the public and private spheres' hermetic character, recognizing the common nature of territorial planning decisions $[10,11]$. It defends fair procedures and resolution practices favoring links and the creation of interactive horizontal relations between representatives of different population groups (or users of the territory), and work and collective learning forms that enable the building of consensus [12]. Citizen participation in these decision-making models, individually or collectively, is a precondition for the exercise of full citizenship. Public policy design and execution are the state's responsibility, such as for environmental policies, proceeding to citizen involvement in the different phases of the decisionmaking models $[13,14]$. Nowadays, citizen involvement occurs mostly in the late stages of the 
models [15]. The present study was designed primarily to evaluate citizens' opinions of the public participation context of environmental and spatial planning, considering two points, (1) who should be involved in the decision-making process, and (2) during which stage of the decision-making process of public policies citizens should be involved and should participate.

\section{MATerials AND MethodS}

The study protocol design is the same as that utilized for the paper previously published by Carreira et al. [16] in the International Journal of Political Science, which studied 250 individuals over 18 years of age who were eligible voters in Portugal, of both genders, and living in Lisbon. A survey of environmental and spatial planning was developed to characterize citizens' opinions regarding the issue of which stage of the decision-making process for public policies citizens should participate in. All individuals participated in a face-to-face interview. Aiming to identify difficulties in answering some questions, a pilot survey was tested on a small sample of 25 individuals. For data statistical analysis, we used the Statistical Package for Social Sciences software $\left(\operatorname{SPSS}^{\circledR}\right)$. The KolmogorovSmirnov test (KS) was used for normality of the data, and the non-parametric independence Chisquare test was used in the inferential statistical analysis. A $95.0 \%$ confidence interval was defined as significant, with $p$-values $<0.05 .^{17-21}$

\section{RESULTS}

Regarding public participation in environmental and spatial planning policies, the majority of the sample (64.8\%) reported that they do not participate, and only $35.2 \%$ said the opposite. Of the latter, $74.6 \%$ only participate when requested, and only $25.4 \%$ do on a voluntary basis. Almost the entire sample (98.8\%) considered that public and political powers should plan together the place where they live, because "...it is those who live in the places that know what, where and when it is missing. For the individuals who reported no need for collaborative practices in planning the territory in which they live (1.2\%), the majority (54\%) considered that local and central government should decide environmental and territorial planning issues together; $23 \%$ considered that only local authorities should take such decisions, as they are better able to understand the reality of the counties, their needs, and their priorities; and 7.6\% considered that only the political central government should have these functions. A significant percentage (15.4\% of the sample) did not answer this question (Figure 1). Some $94.8 \%$ of the sample considered that all the stakeholders (governments, private organizations, and common citizens) should be involved in public policies, and the vast majority of respondents $(82.4 \%)$ considered that the population should participate and be involved "from the very beginning of the project development"- that is, at the embryonic idea time. Only $16 \%$ considered that the population should be involved "during the preparation of the project" (i.e., during the growth and maturation phase of the process); and $1.6 \%$ of respondents were of the opinion that the population should be consulted "after the project drafting have already been completed" (i.e., when it is ready to be implemented in the field) (Figure 2). The study also found that $92 \%$ of the sample shared the view that the decisions and actions taken by political powers to transform the territory of the county where they live in order to improve the quality of life are not understandable. Of the sample, $48.8 \%$ considered these decisions as "weak," $25.6 \%$ as "non-existent," $20.8 \%$ as "reasonable," and only $4.8 \%$ as "good". All respondents (100\%) who said they understood the decisions and actions taken by politicians responded that they did not participate in the environment public policies. Of those who did not understand, $71 \%$ did not participate. A statistically significant relationship between the variables under study - that is, between the fact that individuals did or did not understand decisions and actions taken by politicians - and the level of public participation was achieved $(p=0.011)$. The study also found that $68.8 \%$ of individuals who considered politicians' actions and/or decisions aimed at improving the county's quality of life where citizens live to be "non-existent" did not participate in public policies; those who considered them as "weak" (67.2\%) also did not participate. In contrast, individuals who considered the politicians' actions and/or decisions to be "good" (66.7\%) said they participate whenever they can. So both variables under study - that is, the type of value that every citizen attaches to politicians' actions and/or decisions and the level of public participation in environmental and territory planning policies — presented a statistically significant relationship $(p=$ $0.014)$. 


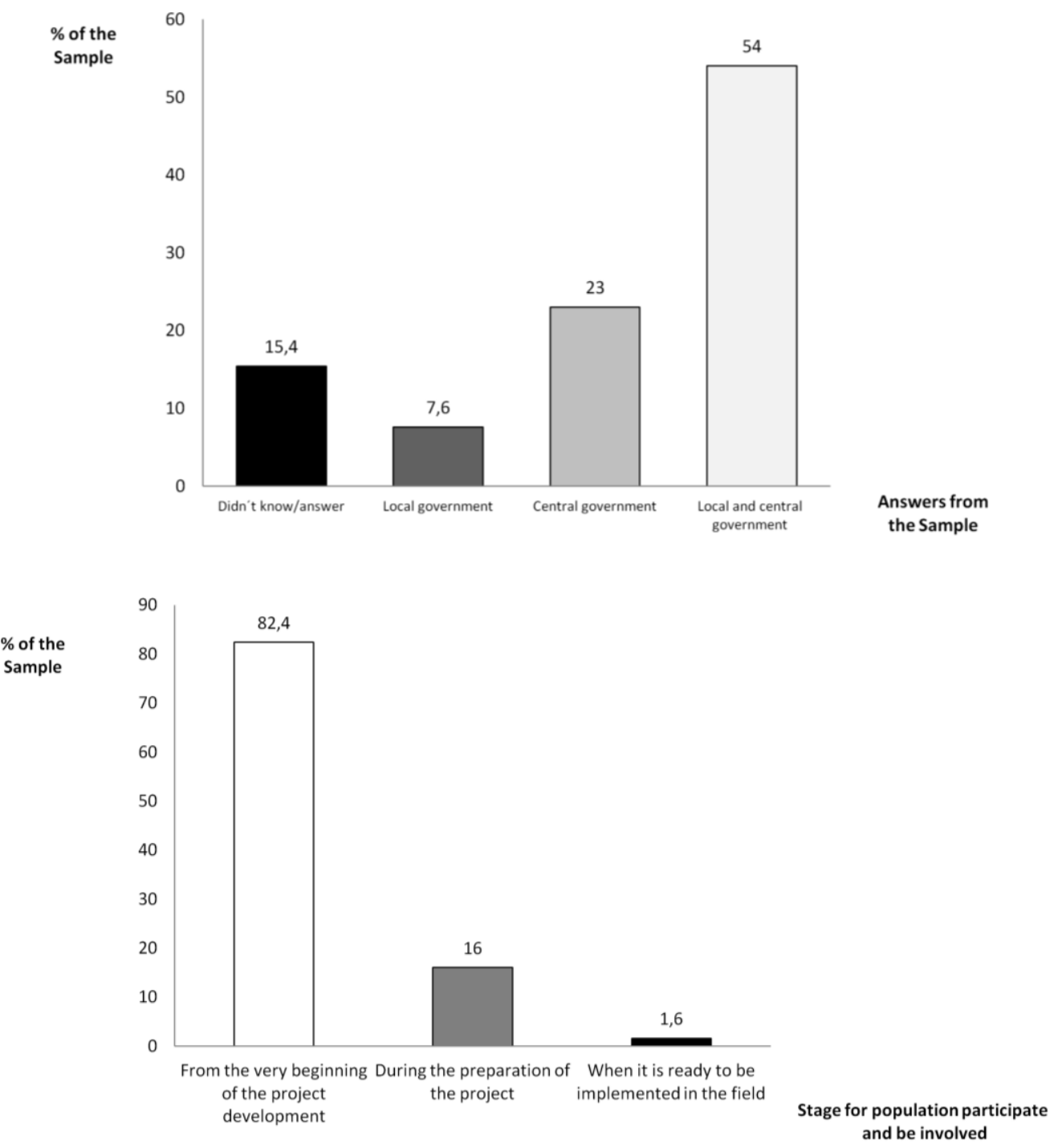

\section{DISCUSSION}

Wider citizen participation in politics always starts with a stake in the social life's microspheres, and the more individuals that participate in them, the better they will participate in macrosphere policy [16-26]. Humans are thinking beings and should be encouraged to make active interventions in the complex socioeconomic and environmental problems where they are inserted [27]. This incentive lies in the democratic state's conduct, fostering among citizens education in active citizenship, which is the nerve center of public participation [28]. The concept of citizenship is often used as a synonym for forms of citizen participation in public life, allowing them access to political, civil, and social rights which result from their own citizenship status. This status guarantees identity and a role in the society to which they belong, fostering a greater ability to respect and co-responsibility for the next citizen, and for the space or land in which they live [29-32].

In Portugal, active participation of citizens has been not witnessed respecting spatial planning and environment, which is not compatible with democratic principles, which call for an increase in public participation [33]. Public participation is the procedure by which citizens interact with the government, which represents those who were elected, to work on decision-making to address problems that directly or indirectly affect them and/or suggest and drive solutions to promote the common good. Portugal has broad and updated legislation on citizen participation rights respecting the decision-making process, although it is not always properly applied by the public administration. There is a lack of preparation in promoting and encouraging the continued practice of active public participation, and the idea that citizens participate only to fulfill a legal and constitutional requirement is still rooted [32-37]. The study results are in line with the Sexton study [38], which stated that 
citizen and stakeholder involvement should always be an integral part of every stage of the decisionmaking process. Only through this proximity of these different actors is it possible to talk about democracy and governance [9].

Governance presupposes interaction and sharing of powers and responsibilities, representing a continuation of the public interest via less authoritarian, hierarchical, and formalized system [39]. In it, work in physical and virtual networks (also called partnerships) that ensure the framework of the formats for participation in order to encourage dialogue on equal terms between several key players so as to reach decision-making based on consensus is predominant [11,40]. These networks live and grow from strategic relationships that complement, influence, and reinforce each other, allowing the educated, aware, and active citizen to take advantage of their existence and decipher the polymorphic nature of the territories in terms of the existing and/or the desired situations [12, 41, 42]. Collaborative practices were upheld by $94.8 \%$ of the sample, who felt that the decision-making process should always involve rulers and the ruled. Almost all respondents (98.8\%) considered that the population should plan together where they live, because "...it is those who live in the places that know what and where is needed, and when is missing." This means that a collaborative or interactive planning model characterized by the recognition of the importance of the common nature of the decision-making process is desirable.

Concerning the citizen involvement phase of the decision-making model, the results obtained from this study align with the idea that the more complex the problem is, the earlier the citizen participation in decision-making should be. Only then is it possible to achieve time and space for debating the issues, in order for all participants to understand the information and the methodology presented, creating the necessary conditions for all involved stakeholders' interests and values to be known. As a result, alternative ideas are shared by all the involved parts of the process, making it possible to adjust the initial plan during the development of the decision-making process so that it suits the real needs of those who live in the territories and those who, through policies, strategies, plans, and projects, have the responsibility to manage them [33,43]. However, this is not the reality experienced by the citizens. The policy platform that exists in Portugal does not provide or sufficiently stimulate a collective dialogue, the redistribution of power, and co-decisions. The result, in the overwhelming majority of cases, is a territorial planning and management deeply entrenched in a centralist and descending model, in which the public actors present the decisions and the citizens passively receive them. This territory planning policy democratic deficit did not escape the attention of the sample, when asked about the level of people's influence in meetings held for the discussion and transmission of information on environmental policy forums, $67.2 \%$ said that there were few participants in those meetings and that the representation of individual citizens was low (13.8\%). Public participation should therefore be an investment made by politicians and citizens. However, according to the results, this is a failure, since $91.9 \%$ of the sample claimed they do not participate in those forums due to lack of time. The reality is that the citizens have almost no free time; therefore, the organization and communication of the maximum amount of information in the shortest period of time should be an obligation of the political sphere in order to encourage and promote citizens in the context of public participation [44-47].

Similar to the Coglianese et al. study [48], some factors that limit and disturb public participation in decision-making were identified in this study, namely: (1) public participation is often limited during the crucial stages of the development of common policies; (2) institutions often prevent communication with external actors; and (3) citizens do not always have immediate access to information, which often does not have the quality necessary for conducting effective participation. In addition, it was also possible to identify other factors that are in line with findings of other authors $[11,12,16,25,26,49-54]$ and that can influence and constrain the ability of citizens to participate and, consequently, to exercise citizenship in these processes, such as (1) the distance from the place of residence of the locals to where the proposed meetings discussing policies will be held, (2) the geographical location where the public session occur (country or city), (3) the time spent in labor or occupations, (4) the frustration generated by non-inclusion of the suggestions made by the public and other interested parties in the decisions, (5) the lack of clear objectives and a way of monitoring the decision-making processes, and (6) the lack of investment in training the citizenship by the government. 


\section{CONCLUSION}

Public participation as an indispensable tool for environment and land planning and management will result in emerging decisions more adapted to reality, to existing priorities, and to the creation of instruments that pursue more sustainable and credible public spatial planning policies. Citizens can and should, therefore, be involved in decision-making processes in the early stages and should have the opportunity to truly influence the decisions handed down. It is the planner's obligation to valorize information and build partnerships, to document participation activities and their results, and to explain at the end how the participation influenced the final decisions made. As a result, the political sphere will show citizens how much their efforts are valued. The politicians gain, the citizens' gain, and the economy, the territory, and the environment gain.

\section{ACKNOWLEDGEMENTS}

The author thank to Anjos of Assis Veterinary Medicine Centre (CMVAA), Barreiro - Portugal, and to MARE NOVA.

\section{REFERENCES}

[1] Amado, M.J.N.P.(2002). O processo do planeamento urbano sustentável. Dissertação para a obtenção do grau académico de doutor em Ciências da Engenharia do Ambiente na especialidade de Planeamento e Ordenamento do Território, Faculdade de Ciências e Tecnologia, Universidade Nova de Lisboa

[2] Correia, J.C.(2004).Comunicação e Cidadania: Os Média e a Fragmentação do Espaço Público nas Sociedades Pluralistas. Lisboa. Livro Horizonte.

[3] Lopes, J.M.P.(2011).Indicadores de monitorização de planos municipais de ordenamento do território. Tese de Mestrado em Engenharia do Ambiente, IST - Lisboa.

[4] Weber, M.(1982).A ciência como vocação: In: Ensaios de sociologia.5 ed. Rio de Janeiro: Zahar,:154-183

[5] Maia, F.S.N. \& Pinto, M.V.L.(2007).Disfunções Burocráticas em Gestão de Pessoas. Trabalho de Conclusão de Curso - Pós Graduação em Gestão de Pessoas, Brasília. Disponível em: $<$ http://portal2.tcu.gov.br/portal/pls/portal/docs/2055758.PDF

[6] Botrel, M.; Araújo, P.G. \& Pereira, J.R.(2010).Entre a Gestão Pública e a Gestão Social de Bens Culturais no Brasil. In Encontro Nacional de Pesquisadores em Gestão Social, 4, Lavras. Anais,Lavras: INCUBACOOP.

[7] Secchi, L.(2009).Modelos organizacionais e reformas da administração pública. RAP — Rio de Janeiro 43(2):347-69, 2009. ISSN: 0034-7612

[8] Innes, J.E. \& Booher, D.E. (1999).Consensus building and complex adaptive systems a framework for evaluating collaborative planning. Journal of the American Planning Association, 65(4):412-423

[9] Dores, A.C.(2009). Processo de participação pública colaborativa em planeamento o estudo de caso do plano de gestão da região hidrográfica do algarve. Tese de Mestrado em Ambiente e Participação. Universidade de Aberta

[10] Shmueli, D.F., Kaufman, S. \& Ozawa, C. (2008). Mining negotiation theory for planning insights. Association of Collegiate Schools of Planning. Journal of Planning Education and Research, 27 ( 3):359-364 DOI: 10.1177/0739456X07311074

[11] Canário, P.; Nogueira, H. \& Andrade, H.(2010). Spatial Modelling of Population Vulnerability to Heat Waves in the Lisbon Metropolitan Area. $3^{\text {rd }}$ European Public Health Conference "Integrated Public Health", Netherlands Public Health Federation (NPHF), European Public Health Association (EUPHA) and Association of Schools of Public Health in the European Region (ASPHER), Amesterdão, 10 a 13 de Novembro

[12] Alves, G.L.(2001). A escola pública desde meados do século XIX. In: A produção da escola pública contemporânea. Campo Grande, MS: ed. UFMS; Campinas, SP: Autores associados

[13] Constituição da República Portuguesa. (2014). Coleção textos da Lei, Coimbra: Editora: Almedina, Portugal

[14] Canotilho, J.J.G.(2003).Direito Constitucional \& Teoria da Constituição. 7ed. Coimbra: Livraria Almedina, Portugal 
[15] Vasconcelos, L. (2001). New forums out of sustainability - recent trens at local level. $1^{\text {st }}$ World Planning Schools Congress ACSP-AESOP-APSA-ANZAPS tongji University, Shangai, China, Jul 11-15

[16] Carreira V; Machado JR; Vasconcelos L. 2016. Legal citizen knowledge and public participation on environmental and spatial planning policies: A case study in Portugal. International Journal of Humanities and Social Science Research (Int J Hum Soc Sci); 2016, Volume 2, (7):28-33, Link: http://www.socialresearchjournals.com/archives/2016/vol2/issue7RegardsInternationa

[17] Massons, D.J. (1999). Métodos estadísticos en ciencias de la Salud. Barcelona, Universitat Autònoma de Barcelona.

[18] Dean, A.G.; Arner, T.G.; Sangam S.; Sunki G.G; Friedman, R.; Lantinga M., et al. (2000). Epi Info. Version 3.3. A database and statistics program for public health professionals for use on Windows 95, 98, NT, and 2000 computers. Atlanta, GA: Centers for Disease Control and Prevention.

[19] Neto, P.L.(2002). Estatística. Editora Edgard blücher,2a ed., São Paulo, Brazil

[20] Muñoz, T. \& Garcia. (2003).El Cuestionario como instrumento de investigación / Evaluacion Disponível:http://personal.telefonica.terra.es/web/medellinbadajoz/sociologia/El_Cuestionario.p df

[21] Amaro A; Póvoa A; Macedo L.(2005). A arte de fazer questionários. Metodologias de Investigação em Educação. Faculdade de Ciências, Universidade do Porto

[22] Pateman, C.(1992).Participação e Teoria Democrática. Rio de Janeiro: Paz e Terra, Brasil

[23] Ahmed S.A. \& Ali S.M.(2011).People as partners: facilitating people's participation in publicprivate partnership for solid waste management. Habitat Int, 30:781-796.

[24] Amorim M.S.S.( 2007). Cidadania e Participação Democrática. Anais do II Seminário Nacional de Movimentos Sociais, Participação e Democracia; 5-27 de Abril,UFSC, Florianópolis, Brasil

[25] Carreira V; Machado JR; Vasconcelos L. 2016. Citizens' Education Level and Public Participation in Environmental and Spatial Planning Public Policies: Case Study in Lisbon and Surrounds Counties. International Journal of Political Science (IJPS); 2016, Volume 2, (3):2534, DOI: http://dx.doi.org/10.20431/2454-9452.0203004

[26] Carreira V; Machado JR; Vasconcelos L. 2016. 2016. Engaging Citizen Participation - A Result of Trusting Governmental Institutions and Politicians in the Portuguese Democracy. Social Science (Soc. Sci.); 2016, Volume 5,(3):40; 1-11: DOI:10.3390/socsci5030040. Link: http://www.mdpi.com/2076-0760/5/3/40

[27] Gomes, C. (2008). O universo do homem social e o lugar da realidade objetiva: um diálogo entre pierre teilhard de chardin e milton santos. Revista bibliográfica de geografía y ciencias sociales, Vol. XIII, n ${ }^{\circ} 772$, Universidad de Barcelona , Espanha, ISSN: 1138-9796.

[28] Benevides, M.V.(1994).Cidadania e Democracia. Lua Nova, São Paulo, 32:5-16.

[29] Madec, A. \& Murard, N.(1998).Numa. Cidadania e Políticas Sociais. Lisboa: Instituto Piaget.

[30] Barata-Moura J.2003.A Cidadania como Cultivo. In: Philosophica, 22:83-98

[31] Águila RDel.(2010).La Participación Politica como generadora de educación cívica y gobernabilidad. In: Revista Iberoamericana de Educación, 12.

[32] Siala E.O. (2015).Factors Influencing Public Participation In Budget Formulation. The Case Of Nairobi County. Tese de Doutoramento apresentada à United States International University

[33] Vasconcelos, L.; Oliveira, R. \& Caser, U.(2009).Governância e Participação na Gestão Territorial,série Politica de Cidades - 5, DGOTDU Politica de Cidades Polis XXI, Lisboa

[34] Stringer L.C.; Dougill E.; Fraser K.; Hubacek C.; Prell \& Reed M.S.(2006).Unpacking "participation" in the adaptive management of social-ecological systems: a critical review. Ecology and Society, 11(2):39.

[35] DeCaro, D.A. \& Stokes, M.(2008).Social-psychological principles of community-based conservation and conservancy motivation: attaining goals within an autonomy-supportive environment. Conservation Biology, 22(6):1443-1451.

[36] Ostrom, E. (2009). A general framework for analyzing sustainability of social-ecological systems. . Journal of Science, 325:419-422. 
Citizen Involvement in the Decision-Making Processes of Environmental and Spatial Planning, and it's Influence on Public Participation: a Case Study of Lisbon

[37] Andraden G.S \& Rhodes J.R.(2012).Protected areas and local communities: an inevitable partnership toward successful conservation strategies? Ecology and Society, 17 (4), 14.

[38] Sexton K. (2013).Evolution of Public Participation in the Assessment and Management of Environmental Health Risks: A Brief History of Developments in the United States. Journal of Public Health Research, 2(2),e18. DOI:org/10.4081/jphr.2013.e18

[39] Aragão, A.(2005).A Governância na Constituição Europeia: uma oportunidade perdida?. Estudos em Homenagem ao Prof. Doutor Lucas Pires. Coimbra: FDUC :105-166.

[40] Innes, J.E. (2004).Consensus building: clarifications for the critics. Plann Theor, 3:5-20.

[41] Cowen, D.D; Smith, N. (2009). After Geopolitics? From the Geopolitical Social to Geo economics. Antipode, 41,(1):22-48. DOI: 10.1111/j.1467-8330.2008.00654.x

[42] Ferrão J.(2010).Pôr Portugal no Mapa. JANUS.NET e-journal of International Relations, N. ${ }^{\circ}$ 1, Outono 2010. Acedido em:observare.ual.pt/janus.net/pt_vol1_n1_art8

[43] Vasconcelos, L.; Fonseca. ( 2006). TAIDIS: cidadania ambiental, informação e participação no contexto da Convenção de AARHUS. Fundação Luso-Americana para o Desenvolvimento, Lisboa

[44] Webere, E.C.(2000).The Practice of Deliberative Democracy: Results From Four Large -Scale Trials .Public Administration Review 60 (4):360 -371

[45] Norris, P.(2003).Deepening Democracy via E-governance: contribution to the World Public Sector Report - E-government at the crossroads. United Nations: [s.n.]

[46] Clift, S.L.(2003).E-government and Democracy: representation and Citizen Engagement in the Information Age. [S.1.]:[s.n.].

[47] Szeremeta J, Kerby R. E-Government: providing value to citizens. public administration and democratic governance: Governments Serving Citizens. Proceedings of $7^{\text {th }}$ Global Forum on Reinventing Government Building Trust in Government, Chapter 6:165-172, 26-29 June 2007, Vienna, Austria

[48] Coglianese C; Kilmartin H; Mendelson E.(2008).Transparency and Public Participation in the Rulemaking Process- A Nonpartisan Presidential Transition Task Force Report. University of Pennsylvania, Law School

[49] Ozawa, C.P. (1996).Science in Environmental Conflicts. Sociological Perspectives, 39(2):219230.

[50] Santos B.S.(2002).Democratizar a Democracia: os caminhos da democracia participativa. Rio de Janeiro, Civilização Brasileira.

[51] Martinez,T.A.\&McMullin,S.L.(2004).Factors affecting decisions to volunteer in non governmental organizations. Environment and behavior, 36 (1).

[52] Propst, D.B., D.L. Jackson, M.H. McDonough, 2003, Public Participation, Volunteerism and Resource -Based Recreation Management in the U.S.: What Do Citizens Expect? Society and Leisure, 26(2), 389-415

[53] Larson, K. \& Lach, D. (2008). Participants and non-participants of place-based groups: an assessment of attitudes and implications for public participation in water resource management. Journal of Environmental Management, 88: 817-830.

[54] Miskowiak, D. (2003). Meaningful to Citizens - Functional for Planning: Using Public Participation Tools to Accomplish Planning Tasks. The Land Use Tracker, 3(3) 